\title{
Unsettled identities amid settled classifications? Toward a sociology of racial appraisals
}

\author{
Wendy D. Roth* \\ Sociology Department, University of British Columbia, Vancouver, Canada
}

This is an Accepted Manuscript of an article published by Taylor \& Francis in Ethnic and Racial Studies in 2018 (vol. 41, issue 6), available online: http://www.tandfonline.com/doi/full/10.1080/01419870.2018.1417616

The citation is:

Roth, Wendy D. "Unsettled identities amid settled classifications? Toward a sociology of racial appraisals.” Ethnic and Racial Studies, 2018, 41(6):1-20.

\begin{abstract}
:
Individuals are claiming greater scope for choice in their racial identities. But how they are seen and classified by others is not necessarily changing in a similar way. Racial appraisals are the way that people classify the race of others, both particular individuals and larger groups. In this paper, I make a case for the study of racial appraisals as a field of sociological inquiry. I map out the different analytical levels and methodological approaches for this field and discuss how these can be used to understand observed race, norms of racial classification, and societal norms of the racial order. I present an example of how societal norms and logics of racial classification can be analyzed in real time through survey research, using 2015-2016 data on 866 White Americans' reactions to Rachel Doležal's racial identity claims. I present an agenda for studying changes in racial boundaries and classification norms through the longitudinal tracking of racial appraisals.
\end{abstract}

Keywords: observed race; race perception; racial classification; norms; multiple dimensions; Rachel Dolezal

Acknowledgments: I would like to thank Catherine Lee, Ann Morning, and John Solomos for valuable comments on this paper. I am also grateful to Matthew Hughey, Phil Kasinitz, Karyn Lacy, Akwugo Emejulu and all the participants of the Ethnic and Racial Studies $40^{\text {th }}$ Anniversary Conference at the University of Warwick for discussion of an earlier version. This work was supported by a Social Sciences and Humanities Research Council of Canada Insight Grant (\#435-2014-0467).

Disclosure statement: No potential conflict of interest was reported by the author.

\footnotetext{
*CONTACT: Wendy D. Roth, wendy.roth@ubc.ca
} 


\section{Unsettled identities amid settled classifications? Toward a sociology of racial appraisals}

The $40^{\text {th }}$ anniversary of Ethnic and Racial Studies offers an opportune moment to consider ways that race scholarship, and perhaps race itself, has changed over the past four decades. One clear change is the transition from thinking of race as inherent, fixed, or given to a view of race as constructed, fluid, or chosen. This mirrors the scholarly shift from an essentialist to a constructivist perspective of race, yet goes further, frequently emphasizing the role of personal agency in racial identity above that of external constraint and classification. Rogers Brubaker, considering the highly contested case of Rachel Doležal's claims to a Black identity, describes an "increasing complexity and fluidity of the landscape of identities. The massive destabilization of long taken-for-granted categorical frameworks has significantly enlarged the scope for choice in the domains of race [and] ethnicity," as well as other identity domains (2016a:415). In this volume, Ann Morning (2018) details new forms of racial membership and belonging, fostered in part by new respect for subjective self-identification. Legal scholar Camille Gear Rich (2014) argues that we are living in an era of "elective race", where individuals increasingly attempt to control the terms on which their bodies are assigned racial meaning.

The prominence given to choice stems partly from the focus on racial identity above other dimensions of race, particularly observed race, or how people are classified by others (Roth 2016). The idea of observed race reflects the fact that people's self-identities may not always match how they are seen by others, and that rather than it being 'incorrect,' how others observe a person's race is itself a distinct dimension of how she or he experiences 'race' in daily life. ${ }^{1}$ Understanding the multidimensionality of race is crucial for considering how race may be changing - or more specifically, which dimensions of race may be changing. Specifically, what is changing is how growing numbers of people think of racial identity; it is in this domain that the enlarged scope for choice has occurred. But observed race - how people are seen and classified by others - is not necessarily changing in a similar way.

As a field, we need to focus more on 'observed race' - and do so at a variety of analytical levels and with different methodological approaches. Some of this work is beginning to be done, focusing on small-scale racial observations of individual-level targets. What is missing from race scholarship are broader approaches focusing on societal-level norms of contemporary racial classification or assessments of the societal racial order. Norms of racial classification change over time, yet we have relatively little research on how and why contested identity claims are accepted or rejected by societies at large. These may be non-normative racial identity claims by multiracial individuals, those who take genetic ancestry tests, people who have been interracially adopted, or publicly contested cases like those of former NAACP-leader Rachel Doležal (Brubaker 2016b), Canadian author Joseph Boyden (Talaga 2017), South Africa's Sandra Laing (Stone 2007), Australian author Colin Johnson (Clark 2004), or U.S. Senator Elizabeth Warren (Hicks 2012). In the United States, where there has been considerable discussion of how the U.S. 
racial order is changing, there is little empirical examination of how the general public views the race of particular groups (e.g. Iranians, Bangladeshis, Latinos/as) or sets of individuals within those groups (e.g. light-skinned Latinos/as) that challenge earlier norms of racial classification.

I refer to the way that people classify the race of others, both particular individuals and larger groups, as racial appraisals. In this paper, I make a case for the study of racial appraisals as a field of sociological inquiry. Although my empirical examples draw primarily from the U.S. context, this scholarship is relevant in many nations, as well as in comparative research. I map out the ways that societal norms and logics of racial classification can be productively analyzed in real time through survey research. And I present an example of how such studies could be done, using 2015-2016 data from a sample of 866 White Americans on their reactions to Rachel Doležal's racial identity claims. Data from a sample of White Americans cannot fully represent broader classification norms among society in general, but provide a partial picture of the logics of racial classification used by this group and a model for how such logics can be empirically evaluated. The case serves as a methodological example and an anchor point for developing a roadmap toward a sociology of racial appraisals.

\section{Racial Frameworks}

I define race as a cognitive structure that divides people into categories, typically ranked hierarchically, on the basis of characteristics believed to be inherent, and often understood as physical or biological characteristics. Those characteristics have traditionally been based on appearance or knowledge of descent (Cornell and Hartmann 1998; Roth 2012). That cognitive structure is a shared representation, learned within a particular society and making up part of its culture. People hold racial schemas - a cognitive bundle of racial categories and the set of rules for what they mean, how they are ordered and relate to one another, and how to apply them to oneself and others (Roth 2012). They learn these schemas, including the norms to apply racial categories according to the standards of the society, through their interactions and observations of others.

Race is also a multidimensional construct. The term "race" subsumes distinct dimensions including racial identity, a person's subjective self-identification and observed race, how she is classified by observers, among many others (Roth 2016). Recent demographic trends such as immigration and interracial marriage have caused the different dimensions of race to increasingly diverge for many populations (Campbell, Bratter, and Roth 2016). This may be an indication that the growing scope for choice in racial identities is unmatched in the realm of observer classifications.

Although the different dimensions of race often influence one another, this is not always the case. The reflected appraisal process holds that people develop self-concepts that reflect the way they believe others think of them (Khanna 2010; Mead 1934). But there are many cases where people's racial identities do not reflect their expected appraisals by others (Vargas and Stainback 2016). Such racial identities may be non-normative or represent situations where norms have not been clearly established, such as for new immigrant groups. These cases 
contribute to the general sense that racial identities have become unsettled and that we are living in an time of "elective race" (Brubaker 2016b; Rich 2014). The question then is whether these elective identities are changing classification norms or not.

\section{Racial Appraisals}

Racial appraisals are the way that people classify the race of others, both particular individuals and larger groups. In interactions between two individuals - an observer and the target of the observation - this is what I have called observed race. But racial appraisals take on different meanings when focused on group-level targets or assessed on a larger scale.

Figure 1 presents a typology of approaches to the study of racial appraisals, distinguished by axes representing the analytical level of the target and the observer(s). Studies that focus on individual-level targets ask about the racial classification of specific individuals, while those with group-level targets ask how entire groups would be racially classified. Those with smallscale observation ask only one or a small number of people to classify others, while those with large-scale observation involve the accumulated appraisals by large, representative samples of observers.

[Figure 1 about here]

I describe the approaches in each of the shaded cells in Figure 1 which form the primary contributions of a sociology of racial appraisals. ${ }^{2}$ Because work in quadrant I is already being done, I advocate for a future research agenda focusing on understanding racial appraisals at the macro level, as in quadrants III and IV.

Studies of observed race (Quadrant I): Studies of observed race - how an individual's race is classified by another individual, usually an interviewer - is the most developed area of scholarship on racial appraisals. A growing number of survey datasets gathered in a face-to-face interview mode include the interviewer's assessment of the respondent's race (Bratter, Campbell, and Roth 2014). A number of surveys collected in other interview modes include reflected race (how the respondent believes she is classified by others) as a proxy for observed race. Those that also include a measure of the individual's racial identity or self-classification allow for analysis of the consistency between these items. Several studies examine the social impacts of observed/reflected race and/or its consistency with self-classification (Bailey, Loveman, and Muniz 2013; Campbell and Troyer 2007; López et al. 2017; Penner and Saperstein 2015; Saperstein, Kizer, and Penner 2016; Telles 2004; Vargas and Kingsbury 2016; Vargas and Stainback 2016). Some argue that observed race more closely matches the mechanisms behind racial discrimination than does racial identity or self-classification (Roth 2010; Saperstein et al. 2016; Telles 2004).

This research provides a crucial assessment of how the racial meaning assigned to different bodies affects people's lives. A valuable contribution to scholarship, it is nonetheless limited by offering the racial appraisal of typically only one observer. These studies cannot 
reveal how much different observers would disagree in their classifications, or whether this particular classification represents how they are seen by the broader society. We know there are interviewer effects whereby the characteristics of observers, such as their own race and gender, influence their racial perceptions of others (Feliciano 2016; Harris 2002). In one of the few studies to examine inter-rater consistency in observed race, Feliciano (2016) asked at least 7 observers to classify the race of each individual depicted in a series of photos and found high consistency between observers in photos of individuals who had self-classified as Black and as White, but less on self-identified Latinas/os and multiracials. The groups where racial identities most often differ from observed race are the same groups with the most observer inconsistency. This suggests that studies of observed race based on a single observation will be less useful for indicating how society perceives individuals in the more racially ambiguous groups that they are often used to study.

Some view the inconsistency between individuals' racial self-classification and their observed race as indicating racial boundary change (Vargas and Kingsbury 2016), or "blurry" racial boundaries (Bailey et al. 2013). ${ }^{3}$ However, a better indication of blurry or blurring boundaries would come from ambiguity or disagreement in how the members of a group are classified by others, particularly by socially dominant groups, rather than discrepancies between racial identities and observer classifications. If all Whites consistently classified all Latinas/os as non-White, this would represent a bright boundary even if all Latinas/os identified themselves as White. The inconsistency between the in-group and out-group's assessments - and the assertion of White identities by Latinas/os in a number of settings - might eventually influence Whites' perceptions and lead to a blurring of the boundary. But whether that happens is an empirical question rather than a foregone conclusion.

A better way to understand the nature of boundaries (bright vs. blurry) is to examine individuals' or groups' racial appraisals by those outside the group, particularly among those with greater power and access to resources. Groups with greater access to resources are the ones that tend to actively maintain the racial boundaries around themselves. As Wimmer writes, "Those who have successfully set themselves apart from the rest of the population [in ethnic terms]... and managed to monopolize economic, political, or symbolic resources will try to police the ethnic boundary and make assimilation and other strategies of boundary crossing difficult" (2008:1002). Although there is a long and brutal history of policing of racial boundaries around Whiteness, in White settler societies in particular, the racially dominant group need not only be the group whose perceptions are relevant. For example, Native Americans have long maintained control over tribal membership and the federal resources it provides (albeit with a history of selfinterested government endorsement) (Snipp 1997). Likewise, the boundaries around Blackness are becoming more carefully policed in an era of Affirmative Action (Brubaker 2016b). Considering how much disagreement there is in observers' racial appraisals of an out-group, particularly within the resource-laden group(s) whose racial boundaries are being tested, offers a better indication of a boundary's strength than whether self-asserted racial identity claims attempt to challenge it. This is what the remaining types of analysis attempt to do. 
Assessments of racial classification norms (Quadrant III): Studies of how a large, representative sample of people classify the race of specific individuals offer a more direct measure of how that individual is generally viewed within society, or within particular segments of it. Essentially a public opinion poll about racial classification, this can account for differences in observer characteristics and explore the logics behind contemporary classification norms or the (in)validation of identity claims. When conducted longitudinally, it would provide an ideal indicator of how norms of racial classification are changing in society.

This research can take different forms. One is to ask how people would classify the race of real individuals in public cases of contested identity claims. When the person's racial identity is known or presented, this takes the form of assessing whether the public validates the person's chosen identity. These studies indicate the general public's current thinking with regard to racial classification of cases that challenge previous norms. The example I provide below in this paper of assessments of Rachel Doležal's identity represents this type. An excellent study asking a representative sample of Americans to fill out the race question on President Obama's census form serves as one of the only other examples of this type of research (Citrin, Levy, and Houweling 2014). ${ }^{4}$

Some studies use experimental designs to evaluate the impact of particular cues or information on racial classification, such as how social status (Freeman et al. 2011; Penner and Saperstein 2008), having a criminal record (Saperstein and Penner 2010), physical features (Gravlee 2005), or knowledge of ancestry (Chen et al. 2017; Citrin et al. 2014; Peery and Bodenhausen 2008) influence how individuals are racially classified. When not conducted with representative samples, these studies do not represent current social norms of racial classification in the society per se, but they shed light on the processes that guide those norms. ${ }^{5}$

Another way to assess norms of racial classification is to provide hypothetical scenarios or vignettes that test identity claims challenging specific racial boundaries in specific ways. While the public personas of Rachel Doležal and Barack Obama evoke emotions unrelated to the analytical questions at stake, vignettes about hypothetical individuals remove those extenuating factors and present only the relevant information for examining how classification norms function. Vignettes can be altered to examine whether populations are more accepting of efforts to cross certain racial boundaries than others, or efforts by individuals with different initial identities or characteristics. While this methodology would provide the clearest indication of whether the unsettled identities of the current age are unsettling observers' classifications as well, there is surprisingly little research adopting this approach. ${ }^{6}$

Assessment of societal norms of the racial order (Quadrant IV): This type of analysis would use large, representative samples to determine how entire groups are seen as fitting into a nation's racial order. Such studies would ask respondents how they classify the race of entire groups, especially those that are racially ambiguous or whose political context of reception is in flux (e.g., North Africans, Somalis, Sikhs in the U.S.; Iranians in Canada; Serbians in Western Europe). This approach can address questions about the racial incorporation of immigrant groups, and when conducted longitudinally it can reveal how racial boundaries are moving. For 
all the debate about how racial orders may be changing (Bonilla-Silva 2004; Frank, Akresh, and Lu 2010; Hochschild, Weaver, and Burch 2012; Lee and Bean 2004; Yancey 2003), relatively little representative data reveals public assessments of how other groups fit into a nation's racial order, particularly among society’s most powerful groups.

Among the few examples of this approach, Lee and Ramakrishnan (2017) examine perceptions of who counts as Asian American. Listing a number of groups (Chinese, Korean, Japanese, Indian, Filipino, Pakistani, and Arabs or Middle Eastern people), they asked a representative sample of Americans if the group is very likely, somewhat likely, or not likely to be Asian or Asian American. They found that the vast majority of all groups reported that Chinese, Japanese, and Koreans are likely to be Asian or Asian American. But there was less agreement over whether Indians and Pakistanis are likely to be Asian among all observers, including other Asian groups. Even though Indians and Pakistanis perceive themselves as Asian, the authors argue that Americans, including other Asian Americans, draw a boundary between East Asians and South Asians. This type of work reveals the cultural perception of where groups fit in the racial order, and can indicate when societal norms of racial ordering differ from official systems of classification.

With this type of work, it is important to differentiate between perceptions of the hierarchical status of a group and its racial classification. In the United States, Asian immigrants may be seen as of higher status than native-born Whites in some instances (Jiménez and Horowitz 2013), but Asians are still racialized as non-White (Tuan 1998). Scholars who ask "Who is White?" or "Are Asians becoming White?" sometimes engage in linguistic slippage if their interest is in whether the socioeconomic achievements and social status of groups like Asians and Latinos have reached parity with (or surpassed) those of Whites. Understanding both the hierarchical positioning of groups and their racial perception are important goals, but they are separate issues requiring distinct research designs.

Together, the different types of research on racial appraisals would contribute a social understanding of how race is seen from the outside. This can shed light particularly on what types of identity claims or racial self-positioning is validated by others, or what attempts at crossing boundaries are accepted or rejected. In the following sections, I consider a particularly controversial case of racial claims making, and provide an example of how studying racial appraisals can reveal racial classification norms using the case of Rachel Doležal.

\section{Research Data and Methods}

Doležal made headlines in June 2015 when this president of the Spokane chapter of the NAACP who had presented herself as Black for several years was "outed" as White by her parents and confronted by reporters. Shortly after her story broke, I was fielding the post-test survey of a randomized controlled trial of genetic ancestry testing among native-born White Americans. The study examined the impact of genetic ancestry testing on conceptions of race, and particularly whether taking the tests promotes an essentialized view of race as genetically determined (AUTHOR 2017). Because public reactions to Doležal's story seemed to shed light 
on public definitions of race, I added questions to the final survey of this ongoing study to gauge respondents' acceptance or rejection of Doležal's identity claims and their rationales. In future research considering this case or others, a nationally representative sample would be preferable.

The study consists of a random sample of native-born non-Hispanic White Americans, aged 19 and older, who were willing to take a genetic ancestry test but had never done so. Respondents were recruited using random digit-dialling to landlines and cell phones across the United States, and screened for eligibility. Quota sampling was used to recruit a sample that matched the national distribution of non-Hispanic Whites on gender, age, region, and education level. A sample of 1,069 agreed to participate and completed a pre-test survey; a total of 567 participants were assigned to a treatment group that received genetic ancestry tests, while the control group of 502 participants did not receive tests. ${ }^{7}$ Approximately 11 months after their initial pre-test survey, and after the treatment group received their test results, all participants were invited to complete a post-test survey. The questions on Rachel Doležal were added to the post-test survey, which was fielded between September 2015 and March 2016 and was completed by 866 respondents, or $81 \%$ of the pre-test sample.

The post-test survey included the following question:

"Over the summer, you may have heard about Rachel Doležal in the news. She was the president of the Spokane, WA chapter of the NAACP who told people she was Black, but it was revealed in the news that she doesn't have any African ancestry. Rachel went on TV and told the world that she really does identify as Black. She is very involved in the African-American community, married a Black man, has a biracial son, has Black adopted siblings, teaches Africana studies, and worked to promote African-American causes. In your opinion, is it acceptable for Rachel Doležal to tell people that she is Black?"

Based on their "yes" or "no" responses to that question, respondents were asked an open-ended follow-up question: "Why do you think it's acceptable/not acceptable for Rachel Doležal to tell people that she's Black?" I developed an inductive coding scheme for the open-ended responses, looking for common themes and patterns in the types of rationales people offered, and applying multiple codes to responses that raised several themes. In addition to the open-ended responses, I present a descriptive analysis of the quantitative data, and the results of binary logistic regression on the odds of saying that it is not acceptable for Doležal to tell people she is Black.

Among the independent variables in the binary logistic regression, I include a pre-test Genetic Essentialism Scale (range 1 to 5), which measures initial belief in a genetic essentialist view of race - that race is genetically determined and that races have innate, core essences. I also include an indicator of respondents' knowledge of basic genetic science (range: 0-3), taken from the Survey on Genomics Knowledge, Attitudes, and Policy Views (Hochschild and Sen 2015), and measured at the pre-test survey. In addition to standard demographic characteristics, I include a measure of political party preferences, and a mean measure of respondents' reported frequency of having a conversation with someone who is Black, Middle Eastern, Asian, Latino, 
or Native American (range: 1 to 7). For further detail on these measures or the study design, see AUTHOR (2017). ${ }^{8}$

\section{Research Findings}

Figure 2 shows descriptive statistics on respondents' acceptance of Doležal's identity claims. The majority of respondents -65.4 per cent - felt that it is not acceptable for Doležal to tell people she is Black, while only 14.5 per cent felt that it was acceptable. This is a fairly clear consensus; most of these native-born Whites reject Doležal's racial identity and appraise her race as White. The open-ended responses shed light on the logics respondents used and their criteria.

[Figure 2 about here]

Table 1 presents the major themes that emerged from respondents who rejected Doležal's racial identity. One-quarter of them explained that they do not view Doležal as Black because they view race as genetically determined. They mentioned Doležal's DNA or her genes as proof that she is not Black. One respondent expressing this theme wrote, "Black is genetically determined. Even if Ms. Doležal identifies with the Black community and culture, she isn't genetically Black." Many of these respondents specifically referred to "Black genes" or "Black blood", suggesting a belief that race is biologically embodied. Although scientific evidence disputes that any genetic markers can definitely determine one's race (Graves 2004), many of these respondents based their rejection of Doležal's identity on precisely this belief.

[Table 1 about here]

About one-fifth of those who rejected Doležal's claims raised "ancestry" as a criterion for racial classification, and noted that Doležal lacked any known African or Black ancestry. Many in this group referred to the social classification of Doležal's parents or grandparents as White as a reason for rejecting her claim, implying a perception that the relevant ancestry should be fairly recent. The short distance of ancestral connections was emphasized by one respondent who wrote:

Apparently she has not African ancestry [sic] and we tend to apply races based on ancestral origins. It is a commonly held opinion that African-Americans, raced as Blacks, hold "recent" ancestral connections to the continent. Since race is applied by society Ms. Doležal cannot make that claim. Certainly she has the right to say she is connected to the black race, in a chosen way, but she is not seen [by] society as a member.

Many listed both ancestry and DNA in their responses, although references to ancestry were less common than those to genes.

Another common theme is the idea that one's race is imposed rather than chosen. This was expressed in several ways, including the themes "Identifying with a group is not the same as belonging to it" (23\%), "Race is not a choice" (9\%), and arguably the fairly common response 
which revealed little more than a firm belief that "She is not Black" (17\%). All of these respondents communicated variants of the idea that "race" is different from a person's feelings, desires, or actions. Representative quotes expressing these themes include:

"Being African-American isn't something that someone can just decide for themselves."

"Because she is not black. You are what you are not what you choose. You can identify with whatever and it does not change the facts."

These responses also imply that race is primordial. They reject the notion of racial fluidity and remind us that, for many people, race is still perceived as innate and fixed.

Many of those who reject Doležal's Black identity focus on the aspects of deception in her story (31\%). Even those who indicated specific criteria for classifying race (e.g., genes, ancestry, appearance) often also indicated that what they found particularly problematic was the perceived misrepresentation from one who knew she did not qualify by those criteria. While many respondents did not expand beyond their belief that she lied (e.g., "A lie is a lie."), others explained how this led to distrust or skepticism that turned many opinions against her:

"I question her motives because she misled others. I would ask why she allowed others [to] make certain assumptions about her (based on appearances and how she portrayed herself and her background). It seems to me that she deliberately misrepresented herself."

"Because she is in a powerful political position that needs someone who doesn't lie about their heritage. If she identifies as black, but does not share the ancestry, that should have been clear from the beginning."

Many cases of contested identity claims involve some element of deception or misrepresentation. Particular aspects of Doležal's narrative, such as her 2002 lawsuit claiming that Howard University discriminated against her as a White person, may lend themselves to greater focus on aspects of deception in her case than others. This calls for empirical comparisons to determine to what extent norms of racial classification are influenced by deception more than the act of adopting a non-normative identity.

Table 2 presents the major themes expressed by people who accepted Doležal's identity claims. Although these responses represent less than one-sixth of the sample overall, they elucidate a minority view that accepts a type of elective race. The most frequent theme in these responses, expressed by $43 \%$ of those who accept Doležal's identity, is the view that race should be about choice. As one respondent said, "She should have the right to define her own identity." Many deferred to Doležal's choice; some claimed it would be racist to tell her she had to identify a certain way. Several expressed a view similar to one respondent who combined a colorblind framework with a recognition that race is still commonly understood as genetic, claiming: "Self identification is more important than genetics."

[Table 2 about here] 
A related theme, expressed by $24 \%$ of this group, adopted a laissez-faire attitude toward racial identity - that Doležal can do what she wants and it is not their place to tell her otherwise. These respondents saw Doležal's identity claims as harmless, and reiterated the emphasis on choice by giving precedence to what a person chooses for herself rather than imposed classifications. Fourteen per cent explicitly recognized the multidimensionality of race by distinguishing racial identity from racial ancestry or genetics. One wrote, "identity is more than those characteristics gained from your genetic material," suggesting that racial identity is subject to choice even if racial ancestry is not.

About one-fifth of these respondents expressed a view that race is determined by one's actions or experience. They referenced the community in which Doležal lives and sought to align herself. These respondents focus on Doležal's recent experience living as a Black person in contrast to those who focused on her early life experiences as White as a reason for rejecting her claims. While lived experience is relevant to some people's understanding of race, it can be defined in different ways.

Smaller numbers referred to race as a social construct or as a cultural identification. A few explicitly referenced the syllogism between accepting transgendered identity claims and racial identity claims, often mentioning the case of Caitlyn Jenner whose story received widespread media attention around the same time as Doležal's (Brubaker 2016b). The reductionist argument that anyone can consider themselves Black because humanity originated in Africa was mentioned by only 3 respondents.

Multivariate analysis can also be used to analyze the determinants of accepting or rejecting identity claims. Table 3 presents logistic regression predicting the odds of Doležal's racial identity. Models 2 and 3 show that a genetic essentialist view of race significantly increases the odds of rejecting Doležal's identity, which is consistent with the qualitative themes. Those who view the Republican Party more favourably than the Democratic Party are also more likely to reject Doležal's identity. This effect remains when controlling for essentialist beliefs, so it may reflect rhetoric within the Republican Party that rejects the liberalism of Western modernity (Morin-Chassé, Suhay, and Jayaratne 2017). People aged 35-54 are also more likely than those who are younger to reject Doležal's identity. The analysis shows no evidence that gender, education, living in the South, or frequency of interactions with non-Whites influence this process.

[Table 3 about here]

\section{Discussion}

This sample of native-born White Americans reveals general adherence to racial classification norms that designate Rachel Doležal as White, not Black. Most respondents broadly reject of the idea of elective race and view race as determined by genetics and/or racial ancestry. A minority of respondents subscribe to a view that race may be chosen, reflecting trends in the United States toward emphasizing self-identification above imposed racial 
classification. If this perspective grows, norms of racial classification may eventually shift to reflect the ongoing trend in unsettled identities. But at least among this population, such a shift remains far away.

This analysis does not represent all Americans, or even all White Americans. It specifically reflects native-born Americans who identify only as non-Hispanic White and who are willing to take a genetic ancestry test. It is possible that the study's focus on genetic ancestry testing may have raised issues of genetics to the fore of respondents' minds. The lack of Black and other Americans in particular limits what it reveals about the current state of U.S. racial classification norms. For these reasons, this analysis is presented here primarily as a model for future research on racial appraisals with more representative samples.

Rachel Doležal has justified her Black identity by saying it is valid because race is socially constructed and not a matter of genetics or ancestry (Morning 2017). Yet if we take seriously the "social" when we describe race as a social construction, then it is not simply a freefor-all where people can choose to be whatever they want. It remains guided by the norms that society has constructed (Osuji 2017). The rejection of Rachel Doležal's Black identity reflects a widely held belief that that some known ancestry or biological descent from the group is a criterion of racial membership. Self-proclaimed racial identities may not be limited by the same restraints, but this is precisely why understanding racial classification norms and how individuals are likely to be perceived and treated in that socially constructed world matters.

\section{Toward a Sociology of Racial Appraisals}

Although individuals and groups are claiming greater scope for choice in their racial identities (Brubaker 2016b; Morning 2018), sociologists need to take seriously the question of whether racial classifications by others are changing in a similar way. Even if we are living in an era of "elective race" (Rich 2014), if other people's racial appraisals remain as fixed as ever then we will see a growing divergence between people's racial identities and their observed race, and more cases of contested identity. This means that racial identity - what we typically measure in social research - will become even less useful as an indicator of the lived experience of race, and therefore of racial disparities and inequality. Certainly the "elective" identity claims of Rachel Doležal were not widely accepted, although she represents an extreme case among contested identities (Brubaker 2016a). More research is needed to assess this and other cases to establish whether greater choice in racial identity is influencing norms of classification. If racial classification norms are remaining relatively fixed, we can expect to see a continued or increasing disparity between self-identification and how people are seen by others. This highlights the need to measure different dimensions of race and to recognize that disparities between racial identity and observed race alone do not signal changing racial boundaries.

If Doležal's case is extreme and affected by her complex personal history, hypothetical cases can be crafted to remove that complexity and also test reactions to specific aspects of boundary crossing. For instance, vignettes could test how respondents would classify a White person who takes a genetic ancestry test and claims to be Black after it reports that she has $5 \%$ 
African ancestry, or $25 \%$, or $50 \%$. Or how they would classify someone who does the same after uncovering a genealogical paper trail revealing similar levels of ancestry. Similarly vignettes could ask how respondents would classify a multiracial person with White and Latina/o parents; with 3 Latina/o and 1 White grandparents; with photos depicting the person looking more White or more Latina/o; with details about their language ability or generational status; or indicating their self-identification as White, Latina/o, or mixed. Comparative research could examine how reactions to similar vignettes, and racial classification norms in general, varies by country. The range of potential variations reveals how much research remains to be done.

The most valuable use of a sociology of racial appraisals would be to track racial classification norms or perceptions of the racial order longitudinally. This would provide the clearest indication of changes in racial boundaries or the racial order. For instance, questions could be added to continuing longitudinal surveys to provide assessments at regular intervals. This would not only track changes, but allow analysis of how major political or historical events and demographic change influence racial classification.

Undoubtedly, asking study respondents how they perceive another person's race may seem distasteful for some researchers. Some may feel that studying racial appraisals serves to reify race, or make study participants feel that researchers signal their approval of this classification process. Studying racial identity and the agency it provides for racially oppressed groups can provide a bit of solace in what otherwise may feel like a scholarship focused on the objectification of others. These are real concerns and researchers must be attentive to these dynamics.

Nonetheless, if race is real in its impact, we must understand that impact; we should not avoid studying how a person's race is seen or classified by others because the process - a process that happens to each of us every day - is distasteful or disturbing. In many ways, this resembles the debate over whether to collect data on race at all. Some claim that collecting data on race can reify it, for instance, reinforcing its association with biology (relative to ethnicity) or making race seem important because it appears on national censuses or social surveys (American Anthropological Association 1997; Nobles 2000). Others maintain that failing to collect data on a socially significant category maintains the status quo and hinders efforts to understand and address racial inequality (American Sociological Association 2003). Importantly, there is no evidence to suggest that not collecting race data reduces racism, discrimination, or belief in racial essentialism (Simon 2008). Not collecting data on racial appraisals is similarly unlikely to stop people from making those appraisals or acting on those perceptions. As race scholars recognize the different dimensions that fall under the umbrella term "race", will we concern ourselves with only the ones that are more palatable or easier to measure, or those that have the greatest impact on social structures of racial inequality? 
${ }^{1}$ The term 'observed race' was introduced by Roth (2010), but the concept goes back farther and has at varying times been called "external racial identity" (Harris and Sim 2002), "racial classification" (Saperstein and Penner 2012), or other terms.

${ }^{2}$ I do not focus on quadrant II as I view the others as more promising avenues for future research. Quadrant II could include qualitative studies of a particular group's perceptions of the racial order or experimental research on perceptions of groups with smaller, non-representative samples.

3 "Bright" boundaries involve an unambiguous distinction, where everyone knows which side of the boundary they are on at all times, whereas "blurry" boundaries allow for ambiguous zones of self-presentation and social representation and distinctions are not always as clear (Alba 2005).

${ }^{4}$ By asking respondents how President Obama should fill out his Census race question, Citrin and colleagues (2014) are asking something slightly different than how respondents themselves would classify Obama's race. They are asking for respondents' perception of what Obama's subjective racial identity should be. Their finding that all respondents are more likely to say 'only Black' when told that Obama himself identifies as only Black suggests that respondents want to accept the identity choices of others, or may feel they have no right to impose their views above Obama's own. We might consider this a unique dimension of race, perhaps a reflected observed race, where observers' classifications are shaped to reflect the self-defined racial identity choices of those they observe.

${ }^{5}$ A literature in experimental social psychology, with important work done by psychologists such as Jennifer Eberhardt, Alex Todorov, and Destiny Peery, also assesses how appearance influences both racial classification and other cognitive tasks like recall and evaluations of faces.

${ }^{6}$ To my knowledge, the only studies that adopt this approach implement it on convenience samples (Chen et al. 2017; Citrin et al. 2014).

${ }^{7}$ This includes both 1,007 cases that were randomly assigned to control and treatment groups and a supplement of additional treatment group participants. Because the purpose of this analysis is not to compare treatment and control groups, I do not limit the sample to those that were randomized.

${ }^{8}$ Available from author on request. 


\section{References}

Alba, Richard. 2005. "Bright vs. Blurred Boundaries: Second Generation Assimilation and Exclusion in France, Germany, and the United States." Ethnic and Racial Studies 28:2049.

American Anthropological Association. 1997. Response to OMB Directive 15: Race and Ethnic Standards for Federal Statistics and Administrative Reporting. Arlington, VA: American Anthropological Association.

American Sociological Association. 2003. The Importance of Collecting Data and Doing Social Scientific Research on Race. Washington, DC: American Sociological Association.

Bailey, Stanley R., Mara Loveman, and Jeronimo O. Muniz. 2013. "Measures of 'Race' and the Analysis of Racial Inequality in Brazil." Social Science Research 42(1):106-19.

Bonilla-Silva, Eduardo. 2004. "From Bi-Racial to Tri-Racial: Towards a New System of Racial Stratification in the USA." Ethnic and Racial Studies 27(6):931-50.

Bratter, Jenifer L., Mary E. Campbell, and Wendy D. Roth. 2014. "Multiple Components of Race Data Library [Online Database]." Retrieved (http://kinder.rice.edu/racedatasets/).

Brubaker, Rogers. 2016a. "The Dolezal Affair: Race, Gender, and the Micropolitics of Identity." Ethnic and Racial Studies 39(3):414-48.

Brubaker, Rogers. 2016b. Trans: Gender and Race in an Age of Unsettled Identities. Princeton, NJ: Princeton University Press.

Campbell, Mary E., Jenifer L. Bratter, and Wendy D. Roth. 2016. "Measuring the Diverging Components of Race: An Introduction.” American Behavioral Scientist 60(4):381-89.

Campbell, Mary E. and Lisa Troyer. 2007. "The Implications of Racial Misclassification by Observers." American Sociological Review 72(5):750-65.

Chen, Jacqueline M., Maria Clara P.de Paula Couto, Airi M. Sacco, and Yarrow Dunham. 2017. "To Be or Not to Be (Black or Multiracial or White): Cultural Variation in Racial Boundaries." Social Psychological and Personality Science 1948550617725149.

Citrin, Jack, Morris Levy, and Robert P.Van Houweling. 2014. "Americans Fill Out President Obama's Census Form: What Is His Race?*." Social Science Quarterly n/a-n/a.

Clark, Maureen. 2004. "Mudrooroo: Crafty Impostor or Rebel with a Cause?" Australian Literary Studies 21(4):101-10.

Cornell, Stephen and Douglas Hartmann. 1998. Ethnicity and Race: Making Identities in a Changing World. Thousand Oaks: Pine Forge Press.

Feliciano, Cynthia. 2016. "Shades of Race: How Phenotype and Observer Characteristics Shape Racial Classification.” American Behavioral Scientist 60(4):390-419. 
Frank, Reanne, Ilana Redstone Akresh, and Bo Lu. 2010. "Latino Immigrants and the U.S. Racial Order How and Where Do They Fit In?" American Sociological Review 75(3):378-401.

Freeman, Jonathan B., Andrew M. Penner, Aliya Saperstein, Matthias Scheutz, and Nalini Ambady. 2011. "Looking the Part: Social Status Cues Shape Race Perception." PLoS ONE 6(9):e25107.

Graves, Joseph L. 2004. The Race Myth: Why We Pretend Race Exists in America. New York: Plume.

Gravlee, Clarence C. 2005. "Ethnic Classification in Southeastern Puerto Rico: The Cultural Model of 'Color." Social Forces 83(3):949-70.

Harris, David R. 2002. In the Eye of the Beholder: Observed Race and Observer Characteristics. Population Studies Center Research Report No. 02-522.

Harris, David R. and Jeremiah Joseph Sim. 2002. "Who Is Multiracial? Assessing the Complexity of Lived Race.” American Sociological Review 67(4):614-27.

Hicks, Josh. 2012. "Did Elizabeth Warren Check the Native American Box When She 'applied' to Harvard and Penn?" Washington Post. Retrieved November 30, 2017 (https://www.washingtonpost.com/blogs/fact-checker/post/everything-you-need-to-knowabout-the-controversy-over-elizabeth-warrens-claimed-native-americanheritage/2012/09/27/d0b7f568-08a5-11e2-a10c-fa5a255a9258_blog.html).

Hochschild, Jennifer L., Vesla M. Weaver, and Traci R. Burch. 2012. Creating a New Racial Order: How Immigration, Multiracialism, Genomics, and the Young Can Remake Race in America. Princeton, N.J.: Princeton University Press.

Hochschild, Jennifer and Maya Sen. 2015. "Genetic Determinism, Technology Optimism, and Race Views of the American Public." The ANNALS of the American Academy of Political and Social Science 661(1):160-80.

Jiménez, Tomás R. and Adam L. Horowitz. 2013. "When White Is Just Alright: How Immigrants Redefine Achievement and Reconfigure the Ethnoracial Hierarchy." American Sociological Review 78(5):849-71.

Khanna, Nikki. 2010. “'If You're Half Black, You're Just Black': Reflected Appraisals and the Persistence of the One-Drop Rule.” Sociological Quarterly 51(1):96-121.

Lee, Jennifer and Frank D. Bean. 2004. "America's Changing Color Lines: Immigration, Race/Ethnicity, and Multiracial Identification.” Annual Review of Sociology 30(1):22142.

Lee, Jennifer and Karthick Ramakrishnan. 2017. "Drawing Boundaries Around Who Counts as Asian American." Retrieved September 1, 2017 (https://thesocietypages.org/specials/drawing-boundaries-around-who-counts-as-asianamerican/). 
López, Nancy, Edward Vargas, Melina Juarez, Lisa Cacari-Stone, and Sonia Bettez. 2017. "What's Your 'Street Race'? Leveraging Multidimensional Measures of Race and Intersectionality for Examining Physical and Mental Health Status among Latinxs." Sociology of Race and Ethnicity 2332649217708798.

Mead, George Herbert. 1934. Mind, Self, and Society. Chicago: University of Chicago Press.

Morin-Chassé, Alexandre, Elizabeth Suhay, and Toby E. Jayaratne. 2017. "Discord Over DNA: Ideological Responses to Scientific Communication about Genes and Race." Journal of Race, Ethnicity and Politics. Retrieved September 11, 2017 (/core/journals/journal-ofrace-ethnicity-and-politics/article/discord-over-dna-ideological-responses-to-scientificcommunication-about-genes-and-race-1/BB9E128B2CB58A392D813769993538D3).

Morning, Ann. 2017. "Race and Rachel Doležal." Contexts 16(2):8-11.

Morning, Ann. 2018. “A Racial Kaleidoscope: New Forms of Race Membership.” Ethnic and Racial Studies ?(?):?

Nobles, Melissa. 2000. Shades of Citizenship: Race and the Census in Modern Politics. Stanford, CA: Stanford University Press.

Osuji, Chinyere. 2017. "Rachel Dolezal: 'Negra Frustrada' (Frustrated Black Woman).” Rutgers Camden Blog. Retrieved September 15, 2017 (https://chinyereosuji.camden.rutgers.edu/2017/05/24/rachel-dolezal-negra-frustradafrustrated-black-woman/).

Peery, Destiny and Galen V. Bodenhausen. 2008. "Black + White = Black Hypodescent in Reflexive Categorization of Racially Ambiguous Faces." Psychological Science 19(10):973-77.

Penner, Andrew M. and Aliya Saperstein. 2008. "How Social Status Shapes Race." Proceedings of the National Academy of Sciences 105(50):19628-30.

Penner, Andrew M. and Aliya Saperstein. 2015. "Disentangling the Effects of Racial SelfIdentification and Classification by Others: The Case of Arrest." Demography 52(3):1017-24.

Rich, Camille Gear. 2014. "Elective Race: Recognizing Race Discrimination in the Era of Racial Self-Identification." Georgetown Law Journal 102:1501-72.

Roth, Wendy D. 2010. "Racial Mismatch: The Divergence Between Form and Function in Data for Monitoring Racial Discrimination of Hispanics." Social Science Quarterly 91(5):1288-1311.

Roth, Wendy D. 2012. Race Migrations: Latinos and the Cultural Transformation of Race. Stanford, California: Stanford University Press.

Roth, Wendy D. 2016. "The Multiple Dimensions of Race.” Ethnic and Racial Studies 39(8):1310-38. 
Saperstein, Aliya, Jessica M. Kizer, and Andrew M. Penner. 2016. "Making the Most of Multiple Measures Disentangling the Effects of Different Dimensions of Race in Survey Research." American Behavioral Scientist 60(4):519-37.

Saperstein, Aliya and Andrew M. Penner. 2010. "The Race of a Criminal Record: How Incarceration Colors Racial Perceptions.” Social Problems 57(1):92-113.

Saperstein, Aliya and Andrew M. Penner. 2012. "Racial Fluidity and Inequality in the United States.” American Journal of Sociology 118(3):676-727.

Simon, Patrick. 2008. "The Choice of Ignorance: The Debate on Ethnic and Racial Statistics in France." French Politics, Culture \& Society 26(1):7-31.

Snipp, C.Matthew. 1997. "Some Observations about Racial Boundaries and the Experiences of American Indians.” Ethnic and Racial Studies 20(4):667-89.

Stone, Judith. 2007. When She Was White: The True Story of a Family Divided by Race. First Edition edition. New York: Miramax.

Talaga, Tanya. 2017. “Joseph Boyden’s Identity Crisis Opens up Questions on Who Is Part of a Community | Toronto Star.” Thestar.com, January 14. Retrieved February 27, 2017 (https://www.thestar.com/news/canada/2017/01/14/joseph-boydens-identity-crisis-opensup-questions-on-who-is-part-of-a-community.html).

Telles, Edward E. 2004. Race in Another America: The Significance of Skin Color in Brazil. Princeton, NJ: Princeton University Press.

Tuan, Mia. 1998. Forever Foreigners or Honorary Whites? The Asian Ethnic Experience Today. New Brunswick, NJ: Rutgers University Press.

Vargas, Nicholas and Jared Kingsbury. 2016. "Racial Identity Contestation: Mapping and Measuring Racial Boundaries.” Sociology Compass 10(8):718-29.

Vargas, Nicholas and Kevin Stainback. 2016. "Documenting Contested Racial Identities Among Self-Identified Latina/os, Asians, Blacks, and Whites." American Behavioral Scientist 60(4):442-64.

Wimmer, Andreas. 2008. "The Making and Unmaking of Ethnic Boundaries: A Multilevel Process Theory.” American Journal of Sociology 113(4):970-1022.

Yancey, George. 2003. Who Is White? Latinos, Asians, and the New Black/Nonblack Divide. Boulder, CO: Lynne Rienner Publishers. 
Table 1: Emergent themes for rejecting Doležal's racial identity

\begin{tabular}{|c|c|c|c|}
\hline Theme & $\mathbf{N}$ & $\%$ & Examples of open-ended responses \\
\hline Race is genetically determined & 129 & 25.8 & "If she is has no black genes then she cannot be black." \\
\hline She lacks African/Black ancestry & 93 & 18.6 & $\begin{array}{l}\text { "Because to say one is 'black' is a definition of a person of African } \\
\text { ancestry." }\end{array}$ \\
\hline She lacks physical characteristics of Blacks & 9 & 1.8 & $\begin{array}{l}\text { "I hate to say it, but it is because she looks white. So it is solely } \\
\text { based on appearance." }\end{array}$ \\
\hline $\begin{array}{l}\text { Identifying with a group is not the same as } \\
\text { belonging to it }\end{array}$ & 113 & 22.6 & $\begin{array}{l}\text { "It would be more appropriate to say she identifies with African } \\
\text { Americans and it is great for her to champion for her friends and } \\
\text { family but that does not make her black." }\end{array}$ \\
\hline Race is not a choice & 45 & 9.0 & $\begin{array}{l}\text { "Because I see 'Black' as a distinction of race, not of lifestyle } \\
\text { choice. I don't think you can opt to be Black." }\end{array}$ \\
\hline She is not Black & 85 & 17.0 & "Because she clearly is not black." \\
\hline Because she lied & 157 & 31.4 & $\begin{array}{l}\text { "Because she knowingly and deliberately misrepresented herself. } \\
\text { This knowing misrepresentation is what made her actions/conduct, } \\
\text { in my opinion, morally wrong." }\end{array}$ \\
\hline She did it to gain advantages & 33 & 6.6 & $\begin{array}{l}\text { "I believe she used that statement to gather personal gains, and had } \\
\text { nothing to do with being black. She wanted the job teaching black } \\
\text { studies and thought she would have a better chance if she was } \\
\text { black." }\end{array}$ \\
\hline She still experiences White privilege & 11 & 2.2 & $\begin{array}{l}\text { "It is the ultimate form of white privilege for her to choose being } \\
\text { black. Black people do not have the choice to say they are white." }\end{array}$ \\
\hline She did not experience growing up Black & 21 & 4.2 & "She hasn't lived what a black person has all her life." \\
\hline Her claims are insulting to Blacks & 6 & 1.2 & $\begin{array}{l}\text { Black people accepted her and now they feel another white person } \\
\text { has tried to make them look like fools. }\end{array}$ \\
\hline Other & 25 & 5.0 & \\
\hline
\end{tabular}

Note: Multiple themes are coded within individual responses. 
Table 2: Emergent themes for accepting Doležal's racial identity

\begin{tabular}{|c|c|c|c|}
\hline Theme & $\mathbf{N}$ & $\%$ & Examples of open-ended responses \\
\hline Race should be about choice & 54 & 42.9 & "Because you should be considered who you identify yourself as." \\
\hline Let her do what she wants. Who cares? & 30 & 23.8 & $\begin{array}{l}\text { "If she is most comfortable as a black person and happy to be } \\
\text { identified as such where is the harm?" }\end{array}$ \\
\hline Race is determined by actions/experience & 28 & 22.2 & $\begin{array}{l}\text { "Because she experiences the world and interacts with it as a black } \\
\text { person." }\end{array}$ \\
\hline $\begin{array}{l}\text { Distinguishing racial identity from racial } \\
\text { ancestry }\end{array}$ & 17 & 13.5 & "Because being black is her identity -- as opposed to her ancestry." \\
\hline Race is a social construct & 12 & 9.5 & $\begin{array}{l}\text { "Because race is... basically a social construct. Why is someone } \\
\text { with the proverbial 'one drop of black blood' considered black, } \\
\text { rather than white?" }\end{array}$ \\
\hline It's a cultural identification & 10 & 7.9 & "Black is a cultural term; she identifies herself with that culture." \\
\hline If gender, then race & 8 & 6.3 & "Because I accept Bruce Jenner as Kaitlyn [sic]." \\
\hline We're all from Africa & 3 & 2.4 & $\begin{array}{l}\text { "We all originally came from Africa. Therefore, I would think we } \\
\text { all share 'black' genes." }\end{array}$ \\
\hline Other & 9 & 7.1 & \\
\hline
\end{tabular}

Note: Multiple themes are coded within individual responses. 
Table 3: Logistic regression predicting the odds of rejecting Doležal's racial identity

\begin{tabular}{|c|c|c|c|c|c|c|c|c|}
\hline \multirow[b]{3}{*}{ Male } & \multicolumn{3}{|c|}{ Model 1} & \multicolumn{3}{|c|}{ Model 2} & \multicolumn{2}{|c|}{ Model 3} \\
\hline & \multicolumn{2}{|l|}{ B } & \multirow{2}{*}{$\frac{\text { S.E. }}{0.157}$} & \multicolumn{2}{|l|}{$\mathrm{B}$} & \multirow{2}{*}{$\frac{\text { S.E. }}{0.159}$} & \multirow{2}{*}{$\frac{\mathrm{B}}{0.054}$} & \multirow{2}{*}{$\frac{\text { S.E. }}{0.159}$} \\
\hline & 0.026 & & & 0.053 & & & & \\
\hline \multicolumn{9}{|l|}{ Age (Omitted=19-34) } \\
\hline $35-54$ & 0.633 & & 0.268 & 0.61 & * & 0.272 & $0.598 *$ & 0.272 \\
\hline 55 and above & 0.206 & & 0.26 & 0.196 & & 0.264 & 0.192 & 0.264 \\
\hline South & -0.168 & & 0.17 & -0.224 & & 0.173 & -0.221 & 0.173 \\
\hline \multicolumn{9}{|l|}{ Education (Omitted=HS or less) } \\
\hline Some college & 0.174 & & 0.292 & 0.181 & & 0.295 & 0.165 & 0.296 \\
\hline College degree & 0.168 & & 0.293 & 0.195 & & 0.296 & 0.17 & 0.297 \\
\hline More than college degree & -0.024 & & 0.296 & 0.124 & & 0.301 & 0.101 & 0.303 \\
\hline Republican leaning & 0.09 & $* * *$ & 0.016 & 0.072 & $* * *$ & 0.017 & $0.072 * * *$ & 0.017 \\
\hline Frequency of conversations with non-Whites & -0.064 & & 0.057 & -0.043 & & 0.057 & -0.042 & 0.058 \\
\hline Knowledge of genetics & -0.281 & $* *$ & 0.096 & -0.147 & & 0.101 & -0.148 & 0.101 \\
\hline Belief in Genetic Essentialism (pre-test) & & & & 0.526 & $* * *$ & 0.124 & $0.529 * * *$ & 0.124 \\
\hline Received genetic ancestry test & & & & & & & 0.157 & 0.152 \\
\hline Constant & 1.175 & $* *$ & 0.406 & -0.641 & & 0.589 & -0.702 & 0.592 \\
\hline-2 log likelihood & \multicolumn{3}{|c|}{1039.995} & \multicolumn{3}{|c|}{1021.245} & \multicolumn{2}{|c|}{1020.179} \\
\hline Nagelkerke R-squared & \multicolumn{3}{|c|}{0.103} & \multicolumn{3}{|c|}{0.131} & \multicolumn{2}{|c|}{0.133} \\
\hline
\end{tabular}


Figure 1: Typology of approaches in a sociology of racial appraisals

\begin{tabular}{|l|c|c|}
\hline \hline & Small-scale observation & Large-scale observation \\
\hline $\begin{array}{l}\text { Individual- } \\
\text { level target }\end{array}$ & I. Observed race & III. Racial classification norms \\
\hline $\begin{array}{l}\text { Group-level } \\
\text { target }\end{array}$ & II. Perception of the racial order & IV. Societal norms of the racial order \\
\hline
\end{tabular}


Figure 2: "In your opinion, is it acceptable for Rachel Doležal to tell people that she is Black?"

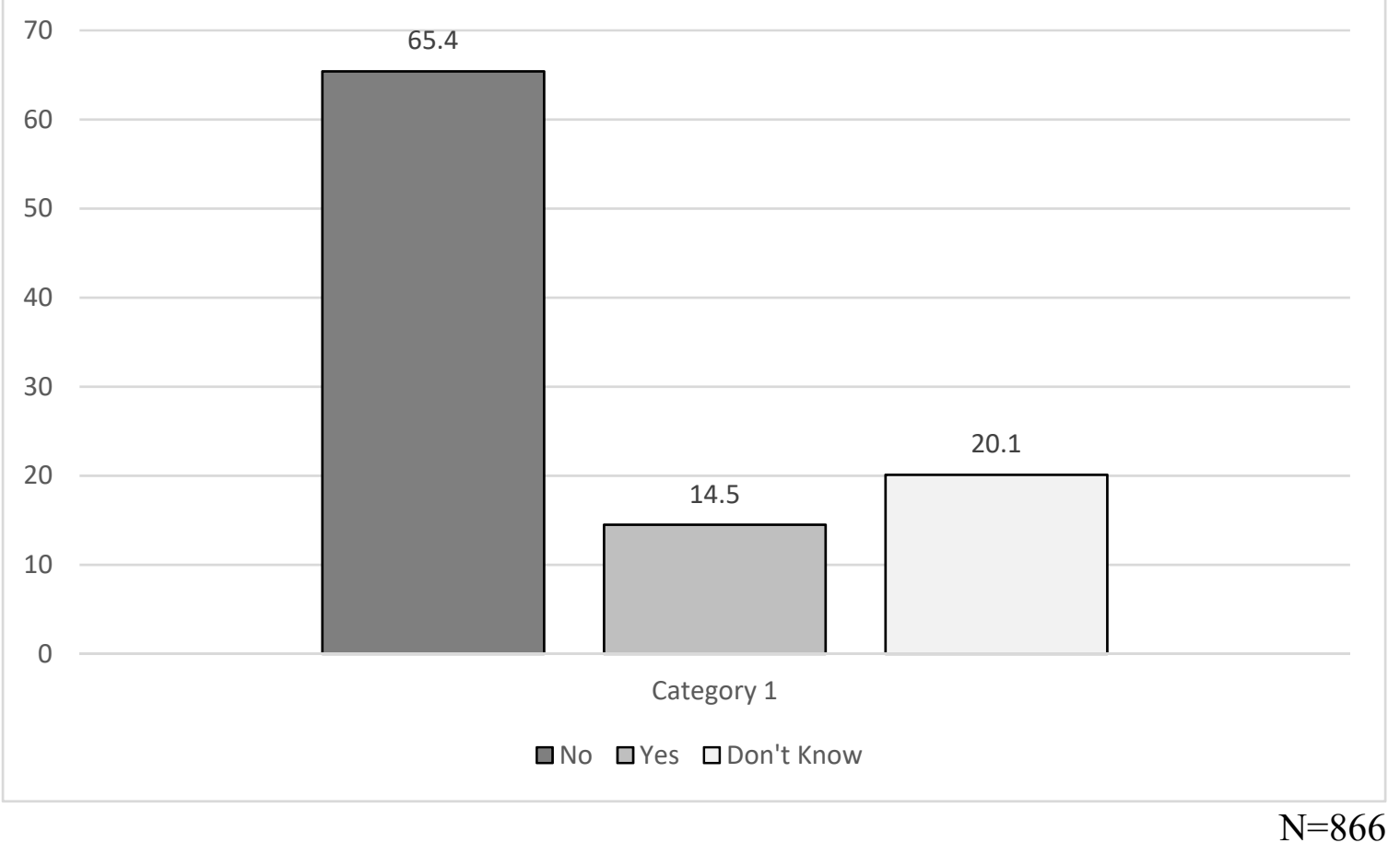

